\title{
Hadith and the Challenges of Islamic Moderation
}

\author{
Ahmad Musyafiq ${ }^{1}$, Tafsir ${ }^{2}$ \\ Universitas Islam Negeri Walisongo Semarang, \\ Indonesia ${ }^{1,2}$ \\ $\left\{\right.$ ahmad_musyafiq@walisongo.ac.id ${ }^{1}$,tafs_pwm@yahoo.com² $\left.{ }^{2}\right\}$
}

\begin{abstract}
Hadith is one of the arguments for extreme attitudes and actions. This paper will analyze why it happens and what the solutions are. Through a contextual hermeneutic approach, this paper found several things. Regarding the use of hadith as one of the arguments for extreme attitudes and actions, this paper found two factors. First, the domination of the Hadith normativity which is positioned as the normativity of al-Qur'an. Whereas the Hadith normativity status is different from al-Qur'an, which in terms of wurūd is qat'iy. Second, the domination of the use of the textual understanding method, especially after there were wide openings for the entry of transnational Islamic organizations. Regarding the solution, this paper offers three notions. First, reducing the dominance of Hadith normativity. This can be done by involving the social sciences and humanities approaches in understanding it. Second, promoting the use of contextual understanding methods, without denying the textual understanding method. Third, using the Sīrah Nabawiyyah as part of the normative sources of the Hadith Nabawi context.
\end{abstract}

Keywords: Hadith Nabawi; the Textual and Contextual Methods; Sìrah Nabawiyyah

\section{Introduction}

Among the sources of Islamic teachings, Hadith is one of the most frequently referred sources for extreme attitudes and actions. Some groups that carry out sweeping refer to the hadith of the Prophet Muhammad regarding the command to change evil. In this hadith, the Prophet Muhammad (pbuh) reminds anyone who sees evil to change it. He gave gradations, starting from changing with actions (bi yadih), with words (bi lisānih) and finally by heart (bi qalbih [1]. They are more motivated, or maybe they don't want to be called having a weak faith, because at the end of the hadith he states that the act of changing evil with the heart is the weakest expression of faith. Another example is the very tough attitude of some Muslims towards non-Muslims which they base on the verses and hadiths.

This reference is an irony. Because by reading the life history of the Prophet Muhammad (pbuh), anyone can conclude that he was a polite and tolerant figure for both Muslims and non-Muslims [2]. But after studying the hadith, they show the opposite attitude. This irony is increasingly apparent in the presence of two other indicators. First, there are several groups and institutions that study hadith that are often associated with extreme attitudes and actions. Second, not a few people who claim to be involved in the field of hadith are also identified with extreme attitudes and actions. This irony is clearly a challenge to Islamic moderation. 
This type of challenge can be said to be even more severe than other challenges, for several reasons. First, the status of the hadith which is one of the normative sources of Islam. So those who use the hadith for the legitimation of an extreme attitude and action feel they have very strong arguments. Second, their limited mastery of the hadith treasures. Because a hadith is ideally not partially understood [3]. Regarding the same problem, there are usually a number of hadiths, which are equally necessary to get the full meaning. Third, the dominant use of textual understanding methods and is often followed by closing opportunities for the use of contextual understanding methods.

\section{Hadith As an Argument for Extreme Attitudes and Actions}

There are many factors associated with referring to the hadith as evidence for extreme attitudes and actions. This paper will limit two factors, namely the dominance of hadith normativity and the domination of the use of textual understanding methods.

\subsection{Domination of Hadith Normativity}

Broadly speaking, some sources of Islamic teachings are normative and some are historical, or some are naqlī and some are 'aqlī. Normative or naqli arguments are arguments based on the dominance of revelation. It is called the domination of revelation, because the material and logic of thought refers to what is contained in the revelation with a very limited use of reason. The point is that the reason in this case is subject to the meaning and logic contained in the revelation. While historical or 'aqli arguments are the arguments based on a larger portion of the use of reason. In this case, there are a number of methods put forward by the scholars. Among those methods, there is a portion of the use of reason that is not too large, because it must still be subject to revelation, such as $i j m \bar{a}^{6}$ and qiyās. There are also methods that use a larger portion of reason, such as istihsān, 'urf and al-maṣlaḥah al-mursalah [4]. So, both naqli and aqli arguments actually rely on revelation. Because this is a religious area, where the main source is revelation.

Hadith includes naqlī or normative arguments. But because of its zannī nature, both wurūd and dalälah, in understanding it the portion of the use of reason should be greater than the one in understanding al-Quran. Because al-Quran wurüd is qat 'cy. But the practice is just the opposite. Even if it is not bigger, the minimum portion of using reason in understanding the hadith is the same as the portion of using reason in understanding al-Quran. This can be seen through two indicators. First, the closure of ar-riwāyah bi al-ma'nā in the hadith [5]. So that from wurūd side, hadith is positioned almost the same as al-Quran. The majority of scholars state that after all the hadiths have been codified into the hadith books, ar-riwāyah bi al-ma 'nā is not allowed. Previously, ar-riwāyah bi al-ma'nā was permitted, but under very strict conditions. The traces of ar-riwāyah bi al-ma'nā allowance can be seen, among others, through the existence of various editorials of hadiths have the same theme, not only in terms of the hadith as a whole, but also in terms of word by word. Because ar-riwāyah bi al-ma 'nā has been closed, so if there is someone who narrates the hadith, but he doubts the similarity between the editorial of the hadith that he narrated with the editorial in the hadith book, then the scholars provide a solution, namely by saying: "Or as the Prophet Muhammad (pbuh) said. (au kamā qāl)“"

Second, the procedure for understanding hadith which also involves a number of conditions, as well as the conditions for understanding al-Quran. In addition, a number of 
knowledge is needed to be able to understand the hadith properly. In fact, some of them are almost the same as those in the group of sciences that must be used to understand al-Quran. For example, if in Ulüm al-Qurān there is Asbāb al-Nuzūl Knowledge, then in Ulüm al-Hadīth there is Asbāb al-Wurūd Knowledge. If in Ulüm al-Qurān there is Knowledge of NāsikhMansükh, in Ulüm al-Hadìth there is also [5]. If it is related to the understanding of al-Quran there are works of tafsìr, then related to the understanding of hadith there are works of sharah hadith. The methods in tafsì are also adapted in the sharah hadith, such as the tahlīli method, the muqāran method, the ijmāli method and the maudiū method. And there are many other sciences that are relatively the same between those in the Ulüm al-Qurān and Ulüm al-Hadìth groups. This similarity shows the strict requirements for understanding hadith. This is what is meant by the dominance of the hadith normativity.

\subsection{The Dominance of Using Textual Understanding Methods}

One of the impacts of the dominance of hadith normativity is the domination of the use of textual understanding methods. Broadly speaking, there are two methods of understanding the hadiths, namely the method of textual understanding and the method of contextual understanding. In use, these two methods of understanding are not contradictory, but complementary. The use of both is also closely related to the type of hadith. There are hadiths that are more appropriately understood textually, there are hadiths that are more appropriately understood contextually and there are hadiths that can be understood both textually and contextually. The problem is when all hadiths are understood textually, or vice versa, all hadiths are only understood contextually [6].

The use of the textual method only for all hadiths will cause many problems, especially those related to certain contexts (sabab al-wurüd). For example the hadith about the command to be tough on non-Muslims. In a hadith it is stated that the Prophet Muhammad (pbuh) ordered Muslims when they came across the Jews to narrow their space. To understand this kind of hadith, it is not enough just by using the textual method of understanding. Because such an attitude does not apply to all time and space. In other words, there is context behind the command. Apart from that, another hadith also found the Prophet Muhammad's command to be tolerant towards non-Muslims. Also found a number of hadiths, where the Prophet Muhammad (pbuh) interacted and even transacted with non-Muslims. These other hadiths clearly reinforce the contextuality of the above hadith.

Just a textual understanding of such hadiths clearly has a very crucial social impact. Especially in the context of the Indonesian nation, one of the pillars of which is Bhineka Tunggal Ika. There will be many psychological and even physical clashes between Muslims and non-Muslims. This symptom began to appear in a number of Muslims. They are very harsh, not only towards non-Muslims, but also towards Muslims who have different understandings from them. There is an only personal impact of dominating the use of textual methods. For example, the hadith about the command to lengthen the beard [7]. Those who understand this hadith textually will think that lengthening the beard is a part of the Sunnah that is highly recommended, even closer to being obligatory to follow because of the editorial of the command sentences used. Likewise the hadiths about $i s b \bar{a} l$, namely the prohibition of lengthening clothes, which are understood narrowly as a prohibition on lengthening pants. However, both types of impacts need to be watched out for. Because if we are not careful, personal impacts can turn into social impacts. For example, if they consider people who do not grow beards and do not shorten their pants as people who oppose the sunnah, they must stay away. 
The impact of using this textual understanding method will be more pronounced when the users do not have sufficient hadith treasures. They only have hadith with a single meaning for each problem. Because, as mentioned in the previous section, almost every problem has various hadiths. There are even various hadiths on the same theme whose meanings contradict one another. This is what gave birth to one of the branches of knowledge in Ulüm al-Hadith, namely the Science of Mukhtalif al-Hadith. One of the solutions offered by this science is to compromise (al-taufiq wa al-jam 'u) [8]. It is in this context that a thematic method of understanding hadith adapted from the method of tafsir is indispensable. Because by compiling all the hadiths that have the same theme, a comprehensive meaning can be found. It may even be possible that various meanings will be found, where each meaning has its own context. If so, then the textual understanding method will not cause much trouble.

\section{Solution Offer}

These challenges to Islamic moderation related to hadiths must be resolved immediately, so that the impact does not spread. This paper will offer three solutions, namely reducing the dominance of hadith normativity, promoting the use of contextual understanding methods and the use of Sirah Nabawiyyah as an additional to the context of Hadith Nabawi.

\subsection{Reducing the Dominance of Hadith Normativity}

This means that the normative value of hadith must be lower than that of al-Quran. This can be done in two ways. First, understanding the hadith within the framework of other established Islamic sciences, particularly Tawheed, Fiqh and Sufism. If there is a hadith related to the issue of Fiqh, then it must be understood in terms of the scientific framework of Fiqh in accordance with the madhhab followed. For example, there are hadiths about certain actions or readings in prayer, then this kind of hadith must be understood in the context of Fiqh in each school. Likewise, if there is a hadith whose meaning is related to Tawheed and Sufism. There are at least two benefits from this kind of method and it will minimize the occurrence of conflict in the community. First, it will not happen that someone simply practices the hadith that is found if the contents are different from the madhhab that is adhered to on the pretext that the hadith is stronger than the opinion of the madhhab. Because it may be that such hadith for the Imam of the Madhhab has lower quality than other hadiths. Second, minimizing the potential of anti-madhhab idea (al-lā madhhabiyyah). Namely the idea not to practice, and directly using al-Quran and al-Hadith. Because the latter understanding has a very large negative impact. Al-Buti even called it the most dangerous bid'ah at this time [9].

Second, including social sciences and humanities, even science and art in understanding hadith. The selection and use of a science is based on the material contained in the hadith that is being understood. In the context of the vision of the Walisongo State Islamic University, this method can be a form of implementation, which is called the humanization of Islamic sciences. There are several benefits that can be obtained from this method. First, the results of understanding the hadith will be more accurate. Because when it comes to certain knowledge, it will be understood within the framework of the related scientific theory. Of course, the theory used should be the one that is already established. This is to minimize the contradiction between hadith and science. Second, fostering a spirit of intellectualism among Muslims. This is important, because nowadays it is indicated by many parties that in terms of science, technology and art, Muslims are lagging behind others. 


\subsection{Promoting the Use of Contextual Methods}

This means increasing the socialization of the importance of using contextual understanding methods in addition to textual understanding methods. This can be done in two ways. First, make use of $a s b \bar{a} b$ al-wurūd. There are two types of asbāb al-wurūd. First, specific asbāb al-wurūd, namely asbāb al-wurūd which is based on narrations, as stated in the asbāb al-wurūd books. Compared to the number of hadiths, the number of asbāb al-wurūd narrations is very small. So that there are still many hadiths that do not have asbāb al-wurüd. Second, general asbāb al-wurūd. Namely asbāb al-wurūd which is not based on a history explicitly called as asbāb al-wurūd, but the life history of the Prophet Muhammad and that which covers him [8]. With this second asbāb al-wurūd concept, the limitations of the first kind of asbāb al-wurūd can be covered. So that almost all hadiths can be placed in the framework of $a s b \bar{a} b$ al-wurūd, both specific and general.

Second, identifying the various roles played by the Prophet Muhammad (pbuh) and linking each hadith with these roles. The identification of the various roles of the Prophet Muhammad (pbuh) actually happened since he was still alive. When he sensed something was wrong, a companion clarified, by asking whether he was in the role of an apostle or as an ordinary human. If he was acting as an apostle, it will be accepted unconditionally. But if he was acting as an ordinary human, then there are companions who ask permission to propose an opinion. Not infrequently he accepted the companions suggestion.

The results of the identification are used to understand the hadith. There are several possible implementations. First, there are hadiths which are only related to the role of apostles. For example, the hadiths regarding tawheed and worship. The hadiths of this type are generally more properly understood textually. Except for the hadiths which contain worship that is furu 'iyyah, it can also be understood contextually. Second, some are only related to the role of an ordinary human being. Generally, the hadiths of this type are more properly understood contextually. Because this type of hadith is related to a certain time and space. This hadith is a form of the Prophet Muhammad's ijtihād. However, in general his ijtihād was still higher than others. Third, there are hadiths related to both roles at once. Generally, the hadiths of this type are better understood both textually and contextually.

\subsection{Sīrah Nabawiyyah as a Normative Source of Hadith Context}

The context of the hadith is usually associated with asbāb al-wurūd. As stated earlier, there is a specific $a s b \bar{a} b$ al-wurūd and a general one. In order to find the context of the hadith, both have limitations. The limitation of the first is that the number is very small compared to the existing hadith. While the limitation of the second is too broad of the material. So it is difficult to find events that will be associated with certain hadiths. These two limitations can be covered by Sirah Nabawiyyah [10]. In addition to the large number of Sirah Nabawiyyah compared to hadiths, the process of identifying events that will be linked to certain hadith is also easier.

For those who are identified as having extreme attitudes and actions, the use of this Sirah Nabawiyyah is more acceptable. First, Sirrah Nabawiyyah is closer to the Hadith Nabawi, because they both rely on riwäyah, even though the reconstruction is looser than the Hadith Nabawi because of the demands of storytelling to be coherent and alive. So that they will not feel they are using sources outside of normative ones. In its history, this Sïrah Nabawiyyah was once part of the Hadith Nabawi. This can be proven through the definition of hadith put forward by muhaddisin. Namely, everything that was relied on to the Prophet Muhammad 
(pbuh), in the form of words, deeds, taqrīr, physical and non-physical characteristics and Sirah, both before and after being appointed as a prophet [5].

Second, nowadays there is a tendency for scholars to write Sirah Nabawiyyah with a selection metode of riwayah similar to those of the Hadith Nabawi and also the tendency to write Sirah Nabawiyyah with other authentic sources, such as the Hadith Nabawi and alQuran. The result is a more valid Sirah Nabawiyyah. The validity achieved can be close to the validity of the Hadith Nabawi. The difference is that the reconstruction is looser, again, because of the demands of storytelling to be more coherent and lively.

The use of Sirah Nabawiyyah as an additional context, in addition to specific and general asbāb al-wurūd, can minimize textual understanding of the hadiths that imply, even command extreme attitudes and actions. Without feeling the use of the name contextual understanding method, which is often avoided by those who have been identified as extreme groups, they have practiced it. In other words, the hadiths which outwardly appear to command extreme attitudes and actions are countered by the same source, namely the Hadith Nabawi or Sirah Nabawiyyah.

\section{Closing}

These three solutions are not without limitations, especially in relation to those who have been identified as having the most extreme attitudes and actions. These limitations include, first, their somewhat closed attitude, making dialogue with them difficult. This is partly because their learning process is more indoctrinated, thus closing the door to dialogue. Second, their tendency to use simple sources or propositions. They are not used to criticize the teachings they receive. In the field of religion, they tend to be taken for granted. Again, this is the effect of an indoctrinal learning model.Therefore, it takes a constant effort to disseminate these offers both to them and to the public at large. This dissemination can be accompanied by dissemination of maquassid al-syarī ah, [11] which is limited in type and number. So there is no need for long-winded discussion. Recently, there have been attempts to study the hadith from the perspective of maqāsidi al-syarī'ah.

Apart from these academic efforts, what is no less important is taking a humanitarian approach to them. Because even though they are tough in their attitudes and opinions, they still have a human nature. In fact, this approach seems important to take precedence. Namely, friendship which is based on a sincere and empathic spirit of brotherhood. If the humanitarian approach is successful, other efforts will be easier.

\section{References}

[1] M. ibn I. Al-Bukhārī, Sahạ̄h Al-Bukhārī Bi Hāsyiyah Al-Sandī. Beirūt: Dār al-Fikr, 1995.

[2] A. Musyafiq, "The Use of Sirah for Hadith Understanding: an Effort to Support Religious Harmony," in International Seminar and Conference 2015: The Golden Triangle (Indonesia-India-Tiongkok) Interrelations in Religion, Science, Culture, and Economic, 2015, pp. 1-9.

[3] N. Hasan, "Faith And Politics: The Rise of The Laskar Jihad in The Era of Transition in Indonesia," Indonesia, no. 73, pp. 145-169, 2002, [Online]. Available:

http://www.jstor.org/stable/3351472. 
[4] A. W. Khallaf, Ilm Ushul al-Fiqh, 2nd ed. Beirut: Dar al-Haramain, 2004.

[5] N. Itr, Manhaj al-Naqd fi Ulūm al-Hadìth, 29th ed. Lebanon Beirut: Dār al-Fikr alMu'āṣir, 2008.

[6] M. S. Ismail, Hadis Nabi Yang Tekstual dan Kontekstual: Telaah Ma'ani al-Hadis tentang Ajaran Islam yang Universal, Temporal dan Lokal, II. Jakarta: Bulan Bintang, 2009.

[7] N. Hasan, "Ambivalent Doctrines and Conflicts in the Salafi Movement in Indonesia," in Global Salafism: Islam's New Religious Movement, R. Meijer, Ed. London: C. Hurst \& Co., 2009, p. 137156.

[8] M. S. Ismail, Hadits Nabi Menurut Pembela, Pengingkar dan Pemalsunya, I. Jakarta: Gema Insani Press, 1995.

[9] M. S. R. Al-Buthi, al-Lamadzhabiyyah Akhtharu Bid'ah fi Zamanina. Beirut: Dar alFikr, 1975.

[10] A. Musyafiq, Konteks Hadis: Telaah Metodologis Penggunaan Sirah Nabawiyah dalam Pemahaman Hadis Nabawi, 1st ed. Semarang, 2016.

[11] J. Audah, Maqāsșid al-Sharī'ah Kafalsafah li al-Tashrī' al-Islāmī Ru'yah Manzūmiyyah, I. USA: al-Ma'had al-Alami li al-Fikr al-Islami, 2012. 